\title{
Weed control trials in sweet cherry peppers in 1991 and $1992^{1}$
}

\author{
Essaú Orengo-Santiago ${ }^{2}$ and Lii Chyuan Liu ${ }^{3}$
}

\begin{abstract}
Two weed control experiments with sweet cherry peppers were conducted on a drip-irrigated Fraternidad clay at the Lajas substation in 1991 and 1992. In the first experiment, plastic mulch on the row plus paraquat at $0.56 \mathrm{~kg}$ ai/ha, directed postemergence between the rows, controlled practically all the weeds. Napropamide at $2.28 \mathrm{~kg}$ ai/ ha and clomazone at $1.12 \mathrm{~kg}$ ai/ha as a pre-plant application, followed by paraquat at $0.56 \mathrm{~kg}$ ai/ha, were less efficient in controlling weeds than plastic mulch plus paraquat. In the second experiment, plastic mulch plus paraquat showed excellent weed control all season long. The pre-plant and postemergence applications of either glyphosate or paraquat also provided good weed control. The use of plastic mulch plus paraquat significantly outyielded all other treatments in both experiments.
\end{abstract}

\section{RESUMEN}

Pruebas en el combate de malezas en ají dulce en 1991 y 1992

En 1991 y 1992 se realizaron dos experimentos de campo en la Estación Experimental Agrícola en Lajas para combatir las malezas en siembras de aji dulce. En el primer experimento, el mejor tratamiento fue el uso de cubierta plástica en el banco más paraquat como posemergente en aplicación directa entre los bancos. Napropamide a razón de $2.24 \mathrm{~kg}$ ia/ha y clomazone a razón de $1.12 \mathrm{~kg}$ ia/ha aplicados presiembra, seguidos por paraquat a razón de $0.56 \mathrm{~kg}$ ia/ha, controlaron las malezas menos eficientemente que la cubierta plástica más paraquat. En el segundo experimento la cubierta plástica más paraquat fue el mejor tratamiento. Las aplicaciones presiembra y posemergente a las malezas de glifosato o paraquat a las dosis recomendadas controlaron las malezas satisfactoriamente. Con el tratamiento de cubierta plástica más paraquat dirigido se obtuvo el mejor rendimiento de aji dulce. Los tratamientos presiembra y posemergente de glifosato o paraquat también controlaron las malezas bien. En ambos experimentos el tratamiento integrado de cubierta plástica más paraquat produjo un rendimiento de aji dulce significativamente mayor que los demás tratamientos.

\section{INTRODUCTION}

Sweet cherry pepper (Capsicum frutescens L.) has been used for a long time as a condiment in Puerto Rican cuisine. In 1991-92, local production reached $362,880 \mathrm{~kg}$ with a farm value of $\$ 420,000$ (1). This level

\footnotetext{
'Manuscript submitted to Editorial Board 26 May 1993.

${ }^{2}$ Assistant Horticulturist, Department of Horticulture.

${ }^{3}$ Plant Physiologist, Department of Crop Protection.
} 
of production has remained stable for the past 5 years. Weed competition is a limiting factor affecting local production of sweet cherry peppers. Many herbicides have been evaluated for weed control in cooking peppers during the past few years $(4,6,7,8)$. However, publications on the use of herbicides for weed control in cherry peppers are scant. Orengo-Santiago et al. (6) evaluated imazethapyr, clomazone, oxyflourfen, napropamide, bentazon, fluazifop and metolachlor for weed control in cherry peppers. Crop injuries resulting from certain herbicides were observed, but higher cherry pepper yields were obtained in comparison to those of the weeded controls. The objective of this study was to evaluate two additional herbicides [glyphosate: $\mathrm{N}$-(phosphomonomethyl) glycine and paraquat: 1,1'-dimethyl-4,4' bipyridinium ion] integrated with plastic mulch to enhance weed control in sweet cherry peppers.

\section{MATERLALS AND METHODS}

First experiment

The experiment was established on a Fraternidad soil (Udic Chromusterts, very fine, montmorillonitic, isohyperthermic) at the Agricultural Experiment Station at Lajas 4 January 1991. A randomized complete block design with four replications was used. Pre-plant application of napropamide (Devrinol) and clomazone (Command) were made 5 February 1991.

$\mathrm{A} \mathrm{CO}_{2}$ pressurized sprayer, fitted with back pack, four-nozzle boom, and Teejet 8001 nozzle tips, was used to deliver $325 \mathrm{~L} / \mathrm{ha}$ spray volume at $289 \mathrm{kPa}$. The 6 -week-old cherry pepper seedlings were planted 2 days later. Three postemergence applications of paraquat (GRAMOXONE SUPER) were made from 4 March 1991 to 5 April 1991, with a knapsack sprayer at a spray volume of $468 \mathrm{~L} / \mathrm{ha}$. Two postemergence applications of fluazifop-P (FUSILADE 2000) and bentazon (BASAGRAN) mixture were similarly made on the same dates. A silver-coated plastic mulch was laid out on top of the rows 1 week before transplanting cherry pepper seedlings. A drip irrigation system similar to that described by Goyal (2) was used throughout the course of this study. Weed control and phytotoxicity were rated periodically. Agronomic and pest management practices followed the commercial usage by farmers in the Lajas region. Cherry pepper fruits were picked 10 times from 6 May 1991 to 22 July 1991.

Second experiment

The experiment was established on the same soil type, adjacent to the first experiment, 3 February 1992. A randomized complete block design with four replications was used. Glyphosate and paraquat were applied to established weeds 2 March 1992. The 6-week-old cherry pep- 
per seedlings were transplanted 1 week later. The silver-coated plastic mulch was used as in the first experiment. Glyphosate and paraquat post-directed were applied at a spray volume of $468 \mathrm{~L} / \mathrm{ha} 6 \mathrm{April}$ and 29 May 1992. Agronomic and pest management practices were similar to those of the first experiment. Ripe cherry peppers were picked eight times from 3 June 1992 to 15 September 1992.

\section{RESULTS AND DISCUSSION}

First experiment

The predominant weed species in plots were wild poinsettia ( $E u$ phorbia heterophylla L.), pigweed (Amaranthus dubius Mart. ex Thell.), morningglory [Ipomoea tiliacea (Willd) Choisy], junglerice [Echinochloa colona (L.) Link], johnsongrass [Sorghum halepense (L.) Pers], large crabgrass [Digitaria sanguinalis (L.) Scop.], purple nutsedge (Cyperus rotundus L.), horse purslane (Trianthema portulacastrum L), and goosegrass [Eleusine indica (L.) Gaertn.]. Plastic mulch plus paraquat at $0.56 \mathrm{~kg}$ ai/ha post-directed between the rows gave the best weed control (table 1). Neither napropamide nor clomazone provided efficient control of broadleaf weeds. Some crop injury in these treatments was caused by the follow-up paraquat application. Clomazone plus fluazifop and bentazon mixture provided good to excellent grass control but poor control of broadleaf weeds.

The highest sweet cherry pepper yield $(19,546 \mathrm{~kg} / \mathrm{ha})$ was obtained in plots with plastic mulch plus paraquat (table 1). Cherry pepper yield obtained with this treatment was twice the expected commercial yield. The increased cherry pepper yields can not be attributed solely to the weed control practice. Goyal et al. (3) indicated that plastic mulch could modify microclimate around the plant, reducing weeds and insect damage. Jones et al. (4) reported that plastic mulch reduced rainfall infiltration through the soil, resulting in decreasing nitrate losses, which contributed to increased tomato yield. Thus, plastic mulch may have contributed to cherry pepper yield increase in our plots. Phytotoxicity in plots receiving herbicide alone treatments may have contributed to lower yields (table 1 ).

Second experiment

The predominant weed species in plots were pigweed, junglerice, morningglory, goosegrass, horse purslane, johnsongrass, red sprangletop [Leptochloa filiformis (Lam.) Beauv.], large crabgrass, and purple nutsedge. Plastic mulch plus paraquat post-directed provided excellent weed control with no phytotoxicity to cherry pepper (table 2). Pre-plant plus postemergence application of paraquat and glyphosate at $1 \%$ and $2 \%$ gave excellent weed control with low phytotoxicity to crop. A second 
TABLE 1.-Effect of herbicide treatments on weed control, phytotoxicity, and yield of sweet cherry peppers in 1991

\begin{tabular}{|c|c|c|c|c|c|c|c|c|c|c|}
\hline \multirow[b]{3}{*}{ Treatment } & \multicolumn{6}{|c|}{ Weed control ${ }^{1}$} & \multicolumn{3}{|c|}{ Phytotoxicity ${ }^{2}$} & \multirow[b]{3}{*}{ Yield $d^{4}$} \\
\hline & \multicolumn{2}{|c|}{$8 \mathrm{WAT}^{3}$} & \multicolumn{2}{|c|}{$11 \mathrm{WAT}^{3}$} & \multicolumn{2}{|c|}{$13 \mathrm{WAT}^{3}$} & \multirow{2}{*}{$\begin{array}{l}8 \mathrm{WAT}^{3} \\
3-4-91\end{array}$} & \multirow{2}{*}{$\begin{array}{l}11 \text { WAT }^{3} \\
2-25-91\end{array}$} & \multirow{2}{*}{$\begin{array}{c}13 \mathrm{WAT}^{3} \\
4-5-91\end{array}$} & \\
\hline & Broadleaf & Grasses & Broadleaf & Grasses & Broadleaf & Grasses & & & & \\
\hline $\mathrm{kg}$ ai/ha & & & & & $\%$ & & & & & $\mathrm{~kg} / \mathrm{ha}$ \\
\hline $\begin{array}{l}\text { Plastic mulching plus } \\
\text { paraquat } 0.56 \mathrm{POE}\end{array}$ & 100 & 100 & 95 & 95 & 95 & 95 & 0 & 0 & 0 & $19,546 \mathrm{a}$ \\
\hline $\begin{array}{l}\text { Napropamide } 2.24 \mathrm{PRE} \\
\text { plus paraquat } 0.56 \mathrm{POE}\end{array}$ & 30 & 38 & 45 & 40 & 75 & 70 & 43 & 50 & 60 & $3,936 \mathrm{c}$ \\
\hline $\begin{array}{l}\text { Clomazone } 1.12 \mathrm{PRE} \text { plus } \\
\text { paraquat } 0.56 \mathrm{POE}\end{array}$ & 36 & 88 & 65 & 65 & 80 & 75 & 35 & 45 & 50 & $4,749 c$ \\
\hline $\begin{array}{l}\text { Clomazone } 1.12 \text { PRE plus } \\
\text { fuazifop } 0.42 \text { plus benta- } \\
\text { zon } 1.12 \text { POE }\end{array}$ & 40 & 89 & 40 & 90 & 60 & 85 & 25 & 35 & 40 & $4,312 \mathrm{c}$ \\
\hline Weeded control & 80 & 80 & 90 & 90 & 100 & 100 & 0 & 0 & 0 & $8,939 b$ \\
\hline
\end{tabular}

${ }^{I}$ Weed control ratings are based on $0-100 \%: 0=$ no control, $100=$ perfect control.

2Phytotoxicity evaluations are based on 0-100\%:0 $=$ no injury, 100 $=$ completely killed.

${ }^{3}$ Evaluation made 1 week after transplanting.

${ }^{4}$ Means with the same letter do not differ significantly at 0.05 probability level. 
TABLE 2.-Effect of herbicide treatments on weed control, phytotoxicity, and yield of sweet cherry peppers in 1992

\begin{tabular}{|c|c|c|c|c|c|c|c|}
\hline \multirow[b]{3}{*}{ Treatment } & \multicolumn{4}{|c|}{ Weed control ratings ${ }^{1}$} & & & \multirow[b]{3}{*}{ Yield $^{4}$} \\
\hline & \multicolumn{2}{|c|}{ Broadleaf } & \multicolumn{2}{|c|}{ Grasses } & \multicolumn{2}{|c|}{ Phytotoxicity $^{2}$} & \\
\hline & $2 \mathrm{WAT}^{3}$ & $5 \mathrm{WAT}^{3}$ & 2 WAT $^{3}$ & 5 WAT $^{3}$ & 2 WAT $^{3}$ & $5 \mathrm{WAT}^{3}$ & \\
\hline $\mathrm{kg}$ ai/ha & & & & & & & $\mathrm{kg} / \mathrm{ha}$ \\
\hline $\begin{array}{l}\text { Plastic mulching on the row plus } \\
\text { paraquat } 0.56 \mathrm{POE}\end{array}$ & 100 & 100 & 100 & 100 & 0 & 0 & $23,040 \mathrm{a}$ \\
\hline $\begin{array}{l}\text { Paraquat } 0.56 \text { Pre-plant plus } \\
\text { paraquat } 0.56 \mathrm{POE}\end{array}$ & 98 & 80 & 99 & 90 & 0 & 5 & $12,807 \mathrm{~b}$ \\
\hline $\begin{array}{l}\text { Glyphosate } 2.24 \text { Pre-plant plus } \\
\text { glyphosate } 2.24 \mathrm{POE}\end{array}$ & 100 & 89 & 100 & 94 & 0 & 10 & $8,616 b c$ \\
\hline $\begin{array}{l}\text { Glyphosate } 4.48 \text { Pre-plant plus } \\
\text { glyphosate } 4.48 \text { POE }\end{array}$ & 100 & 90 & 100 & 92 & 0 & 20 & $7,150 \mathrm{c}$ \\
\hline Wooded control & 0 & 100 & 0 & 100 & 0 & 0 & $9,757 b c$ \\
\hline Non-weeded control & 0 & 0 & 0 & 0 & 0 & 0 & 0 \\
\hline
\end{tabular}

${ }^{1}$ Weed control ratings were made on a scale of 0 to $100 ; 0=$ no control, $100=$ perfect control.

2Phytntoxicity evaluation were made on a scale of 0 to 100; $0=$ no crop injury, $100=$ completely killed.

${ }^{3}$ Evaluation 1 week after transplanting.

${ }^{4}$ Means by the same letter, do not differ significantly at $P=0.05$ level of probability. 
evaluation showed slight crop injury due to drift of paraquat and glyphosate sprays.

The highest cherry pepper yield $(23,040 \mathrm{~kg} / \mathrm{ha})$ was obtained with plastic mulch plus paraquat 0.56 (POE) (table 2). This result agrees with previous findings $(6)$.

Results from this study suggest that plastic mulch plus paraquat post-directed treatment would be a good weed management strategy for cherry pepper production. In a previous experiment on peppers, Liu et al. (5) found that the highest pepper yield and net income were derived from plastic mulch plus paraquat directed treatment. Our results further support their findings.

\section{LITERATURE CITED}

1. Anonymous, 1991. Agricultural Statistics for 1990-91. Office of Statistics, Department of Agriculture, Commonwealth of Puerto Rico.

2. Goyal, M. R., 1983. Labor-input requirements for experimental production of summer peppers under drip irrigation. J. Agric. Univ. P. R. 67: 22-27.

3. - - C. L. Santiago and C. C. de Báez, 1983. How plastic mulch types affect growth parameters of drip irrigated summer peppers. J. Agric. Univ. P. R. 68: 365-373.

4. Jones, T. L., U. S. Jones and D. O. Ezell, 1977. Effect of nitrogen and plastic mulch on properties of troup loamy sand and on yield of "water" tomatoes. J. Am. Soc. Hort. Sci. 102: 273-275.

5. Liu, L. C., M. Antoni-Padilla, M. R. Goyal and J. González-Ibáñez, 1987. Integrated weed management in transplanted tomatoes and peppers under drip irrigation. J. Agric. Uniu. P. R. 71: 349-358.

6. Orengo-Santiago, E., N. Semidey and L. Almodóvar-Vega, 1987. Influence of glyphosate and paraquat pre-transplant treatments on weed control and pepper yields. J. Agric. Univ. P. R. 71: 65-73.

7. --, L. C. Liu and N. Acín-Díaz, 1991. Chemical weed control in sweet cherry peppers. J. Agric. Univ. P. R. 75: 261-268.

8. Reyes-Pérez, L. A., L. C. Liu and L. Almodóvar-Vega, 1986. Integrated weed control in transplanted peppers. Proc. Caribbean Food Crops Soc. 22: 314-330.

9. Semidey, N. and L. Almodóvar-Vega, 1987. Glyphosate on tomato and sweet peppers. J. Agric. Univ. P. R. 71: 209-216.

10. - - E. Caraballo and N. Acín, 1989. Broadleaf weed control in peppers with herbicides applied pre-transplant. J. Agric. Univ. P. R. 73: 67-73. 